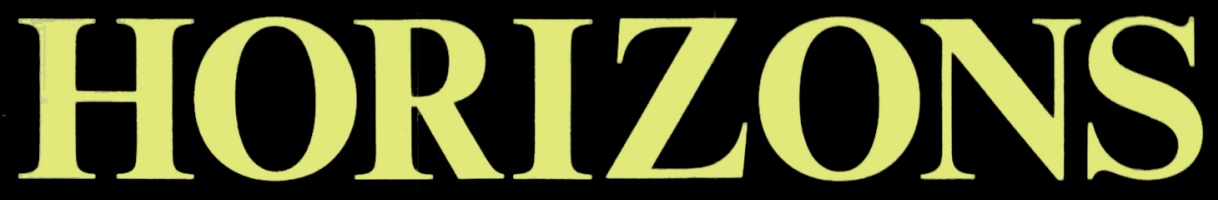

Volume 25

Spring, 1998

Number 1

\title{
ARTICLES
}

Joseph A. Bracken, S.J., Trinity: Economic and Immanent

Nancy A. Dallavalle, Neither Idolatry nor Iconoclasm: A Critical Essentialism for Catholic Feminist Theology

Patrick T. McCormick, How Could We Break the Lord's Bread in a Foreign Land? The Eucharist in "Diet America"

Howard Moltz, A Literary Interpretation of the Book of Amos

\section{EDITORIAL ESSAYS}

Maurice Schepers, O.P., Dialogue and Conversion

Charles J. Sabatino, Spirituality: Experiencing the Everyday World as Grace

\section{REVIEW SYMPOSIUM}

Gerard S. Sloyan's The Crucifixion of Jesus: History, Myth, Faith

Five Perspectives: Marie Anne Mayeski, Lawrence S. Cunningham, Margaret R. Miles, Michael Slusser, Frans Jozef van Beeck, S.J.

Author's Response: Gerard S. Sloyan

Plus Reviews of 28 Books 


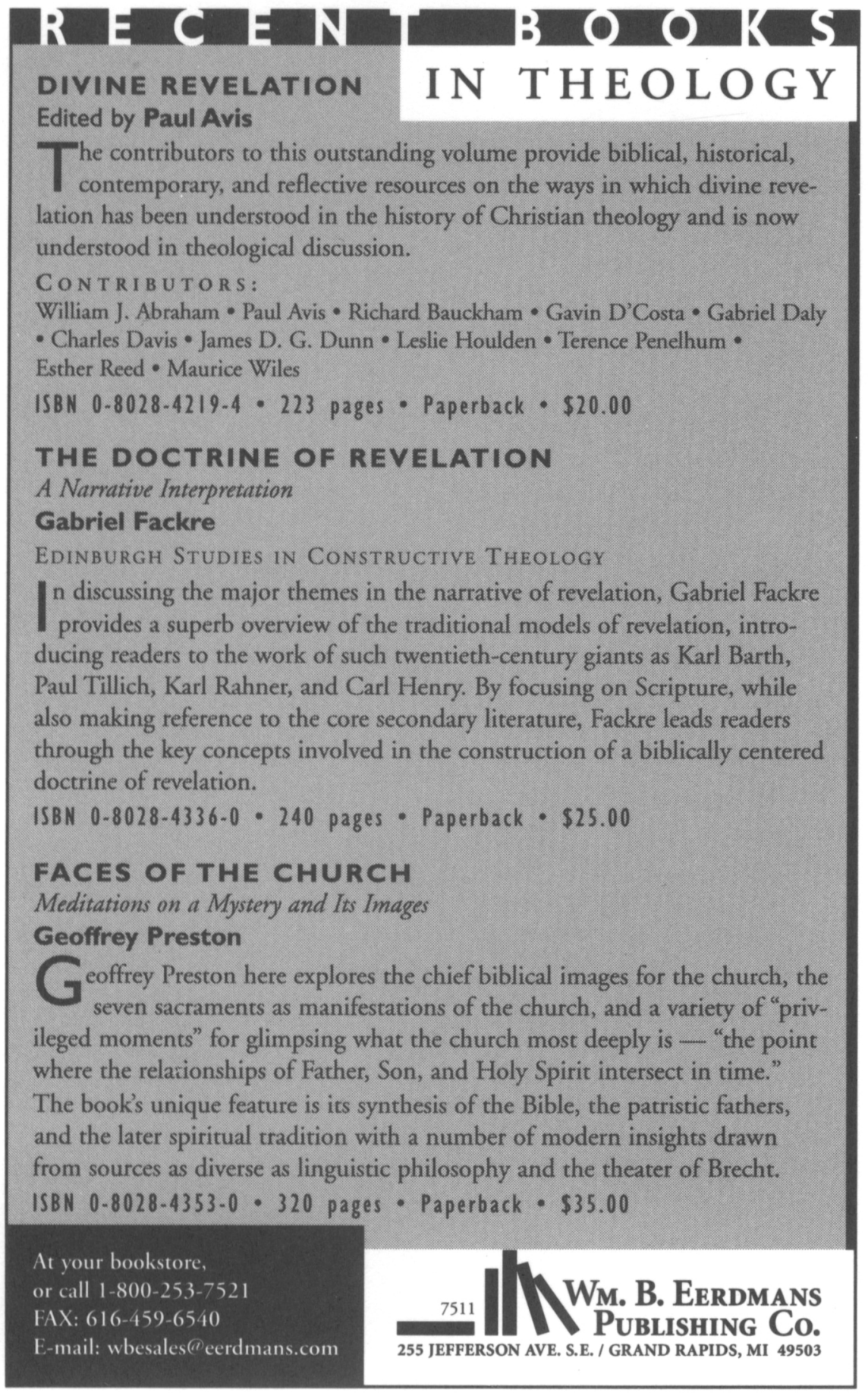




\title{
HORIZONS
}

\section{The Journal of the College Theology Society}

\author{
Published at Villanova University
}

Volume 25

Spring, 1998

Number 1

\section{ARTICLES}

Trinity: Economic and Immanent Joseph A. Bracken, S.J. 7 Neither Idolatry nor Iconoclasm:

A Critical Essentialism for

Catholic Feminist Theology

Nancy A. Dallavalle

How Could We Break the Lord's Bread

in a Foreign Land? The Eucharist

in "Diet America"

Patrick T. McCormick

A Literary Interpretation of the

Book of Amos

Howard Moltz

EDITORIAL ESSAYS

Dialogue and Conversion Maurice Schepers, O.P.

Spirituality: Experiencing the

Everyday World as Grace Charles J. Sabatino

\section{REVIEW SYMPOSIUM}

Gerard S. Sloyan's The Crucifixion of Jesus:

History, Myth, Faith

Five Perspectives Marie Anne Mayeski 95

Lawrence S. Cunningham 98

Margaret R. Miles 100

Michael Slusser 101

Frans Jozef van Beeck, S.J. 103

Author's Response Gerard S. Sloyan 108

\section{BOOK REVIEWS}

Donald K. McKim, Westminster Dictionary of Theological Terms

William Madges 113

Keith Ward, Religion and Revelation: A Theology

of Revelation in the World's Religions

Diarmuid ÓMurchú, M.S.C., Quantum Theology ....... Michael H. Barnes 115 Joseph A. Bracken, S.J., and Marjorie Hewitt

Suchocki, eds., Trinity in Process:

A Relational Theology of God

Donald L. Gelpi, S.J. 116

Karl Rahner, The Trinity Joseph A. Bracken, S.J. 117 
Alan J. Torrance, Persons in Communion: An

Essay on Trinitarian Description and

Human Participation; Thomas F.

Torrance, The Christian Doctrine

of God: One Being Three Persons

Joseph A. Bracken, S.J. 119

Scott Cowdell, Is Jesus Unique?

A Study of Recent Christology Paul F. Knitter 120

Robert Wuthnow, The Crisis in the Churches:

Spiritual Malaise, Fiscal Woe

Bruce H. Lescher 122

Bernard Cooke, The Future of Eucharist:

How a New Self-awareness among

Catholics Is Changing the Way

They Believe and Worship

Nathan D. Mitchell 123

James Allison, Raising Abel: The Recovery

of the Eschatological Imagination

Dermot A. Lane 124

Drew Christiansen and Walter Grazer, eds., "And

God Saw that It Was Good": Catholic

Theology and the Environment

Pamela Thimmes 125

Richard Woods, O.P., Christian Spirituality:

God's Presence through the Ages

Daniel DiDomizio 126

Vivian Green, A New History of Christianity

Gregory Baum, The Church for Others: Protestant

Theology in Communist East Germany

Gary Macy 127

Stanley Hauerwas and Charles Pinches,

Christians among the Virtues: Theological

Conversations with Ancient and

Modern Ethics

Gerard Magill

Charles E. Curran, The Origins of Moral

Theology in the United States:

Three Different Approaches

David W. Haddorff 128

Jeffrey S. Siker, Scripture and Ethics:

Twentieth-Century Portraits

Norbert J. Rigali, S.J.

Anne E. Patrick, Liberating Conscience:

Feminist Explorations in Catholic

Moral Theology Lisa Sowle Cahill

Charles E. Curran, Margaret A. Farley, and

Richard A. McCormick, S.J., Feminist Ethics

and the Catholic Moral Tradition

Timothy E. O'Connell 134

Richard M. Gula, S.S., Moral Discernment

J. Milburn Thompson 135

Moshe Idel and Bernard McGinn, eds., Mystical

Union in Judaism, Christianity, and Islam:

An Ecumenical Dialogue

John P. Boyle 133

Mary M. McGlone, C.S.J., Sharing

Faith across the Hemisphere

L. Michael Spath 136

William J. Bausch, The Parish

of the Next Millennium

Thomas J. Shanahan, S.J. 137

Matthew F. Kohmescher, S.M. 138 
Timothy Walch, Parish School: American Catholic Parochial Education from

Colonial Times to the Present

Francis J. Buckley, S.J. 139

John Polkinghorne, Beyond Science:

The Wider Human Context

William R. Stoeger, S.J. 140

John T. Brinkman, Simplicity: A Distinctive

Quality of Japanese Spirituality

James Fredericks 142

Frederick J. Ruf, Entangled Voices: Genre and

the Religious Construction of the Self

David C. Robinson, S.J. 143

BOOKS RECEIVED

Copyright (C) 1998 College Theology Society

Printed in the United States of America 


\section{HORIZONS}

\section{The Journal of the College Theology Society}

Horizons, The Journal of the College Theology Society is published biannually in Spring and Fall at Villanova University, Villanova, PA 19085.

Yearly subscription: individual $\$ 16.00$, institutional $\$ 40.00$. Send remittance, payable to Wilfrid Laurier University Press, to Wilfrid Laurier University Press, Wilfrid Laurier University, Waterloo, Ontario, Canada N2L 3C5. Changes of address should also be sent to this address. Horizons is automatically received through membership in the College Theology Society.

Manuscripts, editorial and business correspondence, book reviews, advertising copy, and orders for single issues (individual $\$ 8.00$, institutional $\$ 20.00$ ) should be addressed to The Editor, Horizons, Journal of the CTS, Villanova University, Villanova, PA 19085.

In submitting manuscripts, please send four clear copies. Author's name should appear only on an unpaginated cover sheet, with address and essay's title. No other identifying reference to author should appear on the manuscript. All references to author's work in text or notes should be in the third person. Essay's title should appear at top of first page of text. Notes should be placed on separate sheets at end. Full double spacing should be used throughout, including indented quotations and notes. Top, bottom, and right-hand margins should be at least one inch; left-hand margins at least one-and-a-half. Manuscripts should be accompanied by an abstract of one hundred fifty words or less and an author vita of one hundred words or less. Authors should state that the manuscript will not be submitted to another journal until Horizons' evaluation is completed. Manuscripts will be returned if postage is supplied.

Articles appearing in Horizons are abstracted and indexed in: The Catholic Periodical and Literature Index; Guide to Social Science and Religion in Periodical Literature; Index to Religious Periodical Literature; New Testament Abstracts; Religious and Theological Abstracts; and Social Science Citation Index. Articles are indexed in Religion Index One: Periodicals; book reviews indexed in Index to Book Reviews in Religion. Horizons is available in microform from University Microfilms International, 300 North Zeeb Road, Department P.R., Ann Arbor, MI 48106.

\section{(ङ) COLLEGE THEOLOGY SOCIETY}

The College Theology Society is a professional organization of college and university professors of religion in the United States and Canada.

The purpose of the College Theology Society is to improve the quality of the teaching of religion: by stimulating and sharing scholarly research; by developing programs of theology and religious studies which meet student needs and interests; and by exploring, evaluating, and encouraging effective ways of teaching which are interdisciplinary and ecumenical.

Annual membership dues in the Society are $\$ 40.00$ (Full Professional or Associate), $\$ 45.00$ (Joint Professional for husband and wife), and \$20.00 (Graduate Student). Membership in the Society includes a subscription to Horizons. Contact Gary Macy, Theological and Religious Studies Department, University of San Diego, Alcalá Park, San Diego, CA 92110. 


\section{EDITOR}

Walter E. Conn

Villanova University

\section{ASSOCIATE EDITORS}

Lisa Sowle Cahill

Boston College

Denise Lardner Carmody

Santa Clara University

Anne Carr

The University of Chicago

Bernard Cooke

Incarnate Word College

Lawrence S. Cunningham

University of Notre Dame

Charles E. Curran

Southern Methodist University

Margaret A. Farley

Yale Divinity School

Elisabeth Schüssler Fiorenza

Harvard Divinity School
Francis Schüssler Fiorenza Harvard Divinity School

Elizabeth A. Johnson Fordham University

Paul F. Knitter

Xavier University

Pheme Perkins Boston College
Sandra M. Schneiders, I.H.M. Jesuit School of Theology at Berkeley

William M. Shea Saint Louis University

Gerard S. Sloyan

The Catholic University of America

William M. Thompson

Duquesne University

Mary Jo Weaver

Indiana University

BOOK REVIEW EDITOR

Joann Wolski Conn

Neumann College

BUSINESS EDITOR

Anne McGuire

Haverford College

\section{EDITORIAL ASSISTANT}

Irene C. Noble 


\section{HORIZONS}

\section{The Journal of the College Theology Society}

A journal exploring developments in Catholic theology, the total Christian tradition, human religious experience, and the concerns of creative teaching from the college and university environment.

The authors of our four articles cover a lot of interesting theological territory. Howard Moltz takes us back to the Hebrew Scriptures for a new look at Amos in "A Literary Interpretation of the Book of Amos." Joseph Bracken helps us think again about a fundamental trinitarian question in "Trinity: Economic and Immanent." Nancy Dallavalle takes on the thorny issue of essentialism in "Neither Idolatry nor Iconoclasm: A Critical Essentialism for Catholic Feminist Theology." And Patrick McCormick forces us to face some difficult questions about our own lives in "How Could We Break the Lord's Bread in a Foreign Land? The Eucharist in 'Diet America.'"

Our Editorial Essays deal with separation and relatedness. Maurice Schepers examines current ecclesial polarization in "Dialogue and Conversion." And Charles Sabatino considers the interconnectedness of life with Heidegger and Masao Abe in "Spirituality: Experiencing the Everyday World as Grace."

It is really a special occasion to have Gerard Sloyan's The Crucifixion of Jesus as the focus of our Review Symposium. The author responds to the views of Marie Anne Mayeski, Lawrence Cunningham, Margaret Miles, Michael Slusser, and Frans Jozef van Beeck.

It is with great pleasure that I announce that Elizabeth Johnson and Margaret Farley have joined our Editorial Board. And it is with much gratitude that I acknowledge the long and dedicated service of Norbert Rigali and Elena Malits, whose terms on the Board are ending. 